\title{
STUDI VALIDITAS SOAL PILIHAN GANDA BUATAN GURU MATA PELAJARAN GEOGRAFI SMA DI KABUPATEN TANAH DATAR
}

\author{
Oleh: \\ Lailatur Rahmi \\ Dosen Jurusan Geografi FIS Universitas Negeri Padang \\ Email: lailaturrahmi2007@yahoo.com
}

\begin{abstract}
Abstrak
Artikel ini ditulis untuk mengetahui 1. Tingkat kevalidan soal pilihan ganda buatan guru mata Pelajaran Geografi, 2. Faktor penyebab ketidak validan soal buatan guru, 3. Upaya yang dapat dilakukan untuk meningkatkan kualitas soal buatan guru mata Pelajaran GeografiJenis penelitian adalah "Penelitian Deskriptif Kuantilatif" Teknik penarikan sampel adalah cluster random sampling.Teknik analisis data, untuk data kuantitatif menggunakan program ANATES, dan untuk data kualitatif, menggunakan teknik analisis data.Temuan penelitian: Pertama, masih banyak soal ujian semester ganjil buatan guru yang belum valid, dari 50 butir soal yang diujikan $38 \%$ yang valid dan $62 \%$ tidak valid (invalid). Kedua faktor penyebab tidak validnya soal buatan guru adalah : pertama soal yang diujikan masih banyak yang belum sesuai dengan kriteria dari mutu soal yang baik, kedua masih rendahnya tingkat pemahaman siswa terhadap materi yang diajarkan, ketiga belum adanya upaya dari para guru untuk melakukan analisis terhadap hasil penilaian, dan masih rendahnya motivasi siswa serta teknik pembelajaran yang belum bervariasi.Ketiga upaya yang dapat dilakukan untuk meningkatkan kualitas soal buatan guru adalah a) guru-guru harus membuat bank soal, b) guru-guru diberikan kesempatan untuk mengikuti pelatihan-pelatihan, c) semakin menggalakkan MGMP, d) dan setiap guru mata pelajaran diwajibkan untuk membuat, mengolah atau menganalisis kembali butir-butir soal yang diujikan.
\end{abstract}

Kata Kunci: Pembelajaran Geografi, Tes Pilihan Ganda, Tes Buatan Guru, Validitas Soal Pilihan Ganda

\section{PENDAHULUAN}

Pendidikan dalam konteks upaya merekonstruksi suatu peradaban merupakan salah satu kebutuhan (jasa) asasi yang dibutuhkan oleh setiap manusia dan kewajiban yang harus diemban oleh negara agar dapat membentuk masyarakat yang memiliki pemahaman dan kemampuan untuk menjalankan fungsifungsi kehidupan selaras dengan fitrahnya serta mampu mengembangkan kehidupannya menjadi lebih baik dari setiap masa ke masa berikutnya.
Secara formal sistem pendidikan Indonesia diarahkan pada tercapainya citacita pendidikan yang ideal dalam rangka mewujudkan peradaban bangsa Indonesia yang bermartabat.

$$
\text { Undang-Undang Pendidikan }
$$

Nasional Nomor 20 Tahun 2003 Bab II pasal 3 bahwa :

"Pendidikan Nasional berfungsi mengembangkan kemampuan dalam membentuk watak serta peradaban bangsa yang bermartabat dalam rangka mencerdaskan kehidupan bangsa bertujuan untuk mengembangkan potensi peserta didik 
agar menjadi manusia yang beriman dan bertaqwa kepada Tuhan Yang Maha Esa, berakhlak mulia, sehat, berilmu, cakap, kreatif, mandiri dan menjadi warga Negara yang demokratis serta bertanggung jawab”.

Berbicara tentang pendidikan tidak terlepas dari peran guru sebagai tenaga pengajar di sekolah yang merupakan lembaga formal.Guru sangat berperan aktif menciptakan mutu lulusan yang berkualitas dibidang masing-masing, karena guru merupakan ujung tombak pelaksanaan program pendidikan secara keseluruhan.

Sebagai tenaga pengajar, guru memberikan andil yang sangat besar pada kualitas pendidikan yang menjadi tanggung jawabnya, oleh sebab itu untuk meningkatkan kualitas pendidikan maka harus juga ditingkatkan mutu para pengajarnya, salah satunya yaitu meningkatkan mutu guru.

Dalam rangka mengembangkan mutu pendidikan, pemerintah telah melaksanakan berbagai program dan kebijakan melalui mutu tenaga pendidik, adanya upaya pemerintah untuk meningkatkan mutu guru, diharapkan akan lebih mampu untuk menghasilkan keluaran (out put) yang berkualitas yaitu mampu menghasilkan anak didik yang berprestasi secara akademik, walaupun demikian masih banyak guru-guru yang belum memiliki kualitas dan mutu pengajar yang baik dan bahkan belum profesional dibidangnya, salah satunya dapat dilihat dari masih rendahnya hasil belajar yang diperoleh siswa.

Berdasarkan survey yang peneliti lakukan di beberapa SMA Negeri di Kabupaten Tanah Datar, dapat diketahui rata-rata nilai ujian semester siswa SMA
Negeri kelas XI IPS pada mata Pelajaran Geografi sebagai berikut :

Tabel I.1 : Rata-Rata Nilai Ujian Semester 2 Siswa SMA Negeri kelas XI IPS Mata Pelajaran Geografi

\begin{tabular}{|c|l|c|}
\hline No & \multicolumn{1}{|c|}{$\begin{array}{c}\text { Nama-Nama } \\
\text { Sekolah }\end{array}$} & $\begin{array}{c}\text { Rata-Rata } \\
\text { Nilai Ujian } \\
\text { Geografi }\end{array}$ \\
\hline 1. & $\begin{array}{l}\text { SMA Negeri 1 } \\
\text { Pariangan }\end{array}$ & 56,5 \\
\hline 2. & $\begin{array}{l}\text { SMA Negeri 1 } \\
\text { Rambatan }\end{array}$ & 48 \\
\hline 3. & $\begin{array}{l}\text { SMA Negeri 2 } \\
\text { Sungai Tarab }\end{array}$ & 50,6 \\
\hline 4. & $\begin{array}{l}\text { SMA Negeri 2 } \\
\text { Rambatan }\end{array}$ & 48,6 \\
\hline
\end{tabular}

Sumber : Guru Mata Pelajaran Geografi SMA Negeri di Kab. Tanah Datar

Berdasarkan data di atas dapat diketahui bahwa rata-rata nilai hasil ujian semester Genap siswa kelas XI IPS pada mata Pelajaran Geografi di beberapa SMA Negeri di Kabupaten Tanah Datar masih rendah, Kriteria Ketuntasan Minimum (KKM) yang ditetapkan oleh guru berdasarkan hasil Musyawarah Guru Mata Pelajaran (MGMP) Geografi terhadap mata Pelajaran Geografi adalah 75,0.

Peraturan Menteri Pendidikan Nasional Republik Indonesia Nomor 20 Tahun 2007 Tentang Standar Penilaian Pendidikan menyatakan bahwa "Penilaian hasil belajar peserta didik pada jenjang pendidikan dasar dan menengah didasari pada prinsip-prinsip sahih, objektif, adil, terpadu, terbuka, menyeluruh dan berkesinam-bungan, sistematis, beracuan kriteria, dan akuntabel. Sedangkan yang berkaitan dengan Instrumen penilaian yang digunakan oleh satuan pendidikan dalam bentuk ujian sekolah /madrasah memenuhi persyaratan substansi, konstruksi, dan bahasa, serta memiliki bukti validitas empirik" 
Dijelaskan pula dalam Peraturan Menteri Pendidikan Nasional Republik Indonesia Nomor 19 Tahun 2007 tentang Standar Pengelolaan Pendidikan yang berkaitan dengan penilaian hasil belajar peserta didik bahwa penilaian yang didokumentasi-kan disertai bukti kesahihan, keandalan, dan dievaluasi secara periodik untuk perbaikan metode penilaian.

Berpedoman pada Peraturan Pemerintah di atas, disetiap ujian yang dilaksanakan oleh sekolah/madrasah, maka soal-soal yang diujikan kepada siswa harus memenuhi persyaratan, salah satu syarat yang harus dipenuhi adalah harus adanya bukti validitas empirik atau sejauh mana ketepatan butir soal dapat mengukur kompetensi yang diharapkan.

Survey awal yang peneliti lakukan terhadap beberapa SMA Negeri di Kabupaten Tanah Datar, terhadap soal ujian, dari 50 butir soal yang di ujikan kepada siswa, rata-rata hanya $20 \%$ dari soal tersebut yang valid, sedangkan $80 \%$ nya lagi termasuk dalam kriteria tidak valid atau invalid, sehingga hal tersebut ikut berpengaruh terhadap hasil belajar siswa.

Dari soal yang diujikan kepada para peserta didik, ternyata soal tersebut merupakan soal yang dibuat oleh guruguru mata Pelajaran Geografi berdasarkan Hasil Musyawarah Guru Mata Pelajaran (MGMP) Geografi dan Musyawarah Kerja Kepala Sekolah (MKKS) SMA Negeri di Kabupaten Tanah Datar, dan setelah mengkomfirmasi lebih lanjut dengan guruguru yang membuat soal tersebut, ternyata para guru mengungkapkan bahwa mereka belum pernah melakukan pengujian tehadap tingkat kesahihan soal tersebut sehingga kualitas tes atau tingkat kesahihan dan keterandalannya masih belum terjamin.

Berdasarkan permasalahan diatas maka penulis berkeinginan untuk melakukan penelitian tentang : Studi Validitas Soal Pilihan Ganda Buatan Guru Mata Pelajaran Geografi SMA Di Kabupaten Tanah Datar.

Kata geografi berasal dari bahasa Yunani yaitu dari geos yang artinya bumi dan grafien yang artinya melukiskan, menceritakan, atau menguraikan tentang bumi (geosfer).Berdasarkan hasil seminar dan loka karya para pakar geografi sebagai berikut : Geografi adalah pengetahuan mengenai persamaan dan perbedaan gejala alam dan kehidupan di muka bumi (gejala geosfer) serta interaksi antara manusia dengan lingkungannya dalam konteks keruangan dan kewilayahan.

Pembelajaran geografi yang dimaksudkan adalah pembelajaran yang sesuai dengan Standar Kompetensi dan Kompetensi Dasar yang diajarkan dikelas XI IPS yaitu materi tentang fenomena biosfer dan antroposfer, aspek kependudukan, sumber daya alam, dan pemanfaatan sumber daya alam.

Menurut Antasari dalam Sudijono (1996 : 66) dalam karya tulisnya berjudul Psychological Testing yang dimaksud dengan tes adalah alat pengukur yang mempunyai standar yang objektif sehingga dapat digunakan secara meluas, serta dapat betul-betul digunakan untuk mengukur dan membandingkan keadaan psikis atau tingkah laku individu.

Menurut Anwar dalam bukunya Penilaian Berbasis Kompetensi (2008 : 31) mengungkapkan tes pilihan ganda adalah tes yang terdiri dari satu pernyataan soal dengan beberapa alternatif jawaban. Dari alternatif jawaban yang ditawarkan, hanya 
ada satu jawaban yang benar, yang lainnya adalah pengecoh (distractors).Tes ini dikatakan objektif karena opsi pilihannya hanya ada satu jawaban benar, selain itu adalah opsi yang salah.

Arikunto (2006:224) mengatakan tes buatan guru adalah tes yang disusun sendiri oleh guru dengan prosedur tertentu tetapi belum mengalami uji coba berkalikali sehingga tidak diketahui ciri-ciri dan kebaikannya.

Menurut Basrowi (2012:61) validitas adalah suatu proses yang dilakukan oleh penyusun atau pengguna instrument untuk mengumpulkan data secara empiris guna mendukung kesimpulan yang dihasilkan oleh skor instrument. Dengan kata lain, validitas adalah kemampuan suatu alat ukur untuk mengukur sasaran ukurnya.

Ada tiga macam validitas tes yang dikemukan oleh Crocker dan Algina (1986) yaitu validitas isi (content validity), validitas kriteria (criterion-related validation), dan validitas konstruk (construct validation).

Validitas dalam artikel ini difokuskan pada validitas kriteria / empiris yaitu pengukuran terhadap hasil belajar yang diperoleh oleh para testee, yang nantinya akan diolah oleh peneliti untuk mengetahui valid atau tidaknya soal yang diujikan, dengan menggunakan rumus atau formula yang telah ditentukan yaitunya dengan menggunakan program ANATES Verb 4.0.9 hasil Rancangan Drs. Karno To, M.Pd dan Yudi Wibisono, ST.

\section{METODE PENELITIAN}

Berdasarkan masalah dan tujuan penelitian, maka penelitian ini merupakan penelitian yang bersifat "Deskriptif Kuantilatif', (gabungan antara kualitatif dengan kuantitatif, Brannem:1996) yaitu menggunakan data kuantitatif dengan teknik deskriptif.Data yang dikumpulkan dideskripsikan menggunakan tabel atau grafik.Dalam pengumpulan data juga digunakan pendekatan kualitatif untuk melengkapi data yang diperlukan.

Penelitian ini dilaksanakan di beberapa SMA Negeri di Kabupaten Tanah Datar, dalam waktu (tiga) 3 bulan dan terhitung sejak Desember 2012 sampai Februari 2013.Sesuai dengan tujuan penelitian yang menjadi populasi dalam penelitian ini adalah seluruh SMA Negeri di Kabupaten Tanah Datar yang terdiri dari 15 SMA Negeri.

Sampel ditetapkan dengan menggunakan teknik cluster random sampling yang dilakukan dengan 2 tahap, tahap pertama menentukan sampel daerah, dan tahap kedua menentukan orang-orang yang ada didaerah tersebut. SMA Negeri yang dipilih sebanyak 5 buah yaitu SMA Negeri 1 Pariangan SMA Negeri 1 Rambatan , SMA Negeri 2 Batusangkar, SMA Negeri 2 Sungai Tarab, SMA Negeri 2 Rambatan. Berdasarkan ketentuan diatas, maka sampel responden dalam penelitian ini adalah siswa kelas XI IPS, tim pembuat soal ujian geografi guru-guru mata pelajaran geografi dan kepala sekolah di SMA Negeri di Kabuapetn Tanah Datar.

Untuk menentukan jumlah sampel pada siswa kelas XI IPS dimasing-masing sekolah maka penarikan sampel yang digunakan adalah proporsional random sampling.. Teknik pengambilan sampel untuk guru mata pelajaran geografi dilakukan dengan teknik bertujuan (purposive sampling).

Jenis data yang digunakan adalah data primer dan data sekunder.Sumber data dari Dinas Pendidikan Kabupaten Tanah Datar, Waka Kesiswaan dan Wali Kelas 
dari masing-masing SMA Negeri di Kabupaten Tanah Datar.

Untuk soal-soal pilihan ganda yang pernah diujikan, kunci jawaban, lembar jawaban ujian siswa yang akan dianalisis dan hasil belajar siswa berupa nilai yang diperoleh siswa, diperoleh dari guru-guru mata Pelajaran Geografi.Cara pengumpulan data yang dipakai dalam penelitian ini adalah melalui observasi, wawancara dan studi dokumenter.

Perangkat tes dalam penelitian ini berbentuk tes pilihan ganda (multiple choise), untuk mengukur tingkat kevalitan soal buatan guru digunakan program ANATES (Analisis Tes) Ver 4.0.9 hasil rancangan Drs. Karno To, M.Pd dan Yudi Wibisono ST. Untuk mengumpulkan data kualitatif, mengenai faktor penyebab ketidak validan soal buatan guru mata Pelajaran Geografi dan upaya peningkatan kualitas soal buatan guru digunakan pedoman wawancara.

Teknik analisis data kuantitatif adalah menggunakan program ANATES (Analisis Tes) Ver 4.0.9 dan kemudian diterjemahkan dalam bentuk narasi.Untuk analisis data kualitatif menggunakan Teknik Analisis Data yaitu analisis Reduksi Data, Display Data, Pengambilan Keputusan.

Menurut Moleong (2009:327) untuk pemeriksaan keabsahan data dapat dilakukan dengan berbagai cara, yaitu : Perpanjangan Keikutsertaan Ketekunan Pengamatan, Triangulasi, Menggunakan Bahan Referensi, dan Pemeriksaan Teman Sejawat.

\section{HASIL DAN PEMBAHASAN}

Berdasarkan hasil penelitian dan deskripsi hasil penelitian, maka pembahasan hasil penelitian sebagai berikut :

Pertama berdasarkan hasil analisis validitas butir soal-soal pilihan ganda Ujian Semester Ganjil pada mata Pelajaran Geografi kelas XI IPS SMA Negeri di Kabupaten Tanah Datar, dari 50 buah soal yang diujikan $38 \%$ soal yang valid, dan $62 \%$ soal yang tidak valid (invalid).

Dari hasil analisis yang dilakukan dari 50 butir soal yang ada, 38\% atau sekitar 13-24 butir soal yang valid, dan $62 \%$ atau sekitar 17-37 buah butir soal yang tidak valid. Dapat ditarik kesimpulan bahwa soal-soal pilihan ganda buatan guru mata pelajaran geografi SMA Negeri di Kabupaten Tanah Datar masih banyak yang belum valid.

Kedua berdasarkan hasil wawancara dengan tim pembuat soal dan juga sebagai guru mata pelajaran geografi, penyebab dari tidak validnya soal buatan guru mata pelajaran geografi adalah pertama tes yang diujikan kepada siswa belum pernah dilakukan pengujian, baik itu terhadap tingkat kevalidan soal, reliabilitas, maupun daya bedanya. Untuk bahasa yang digunakan pada soal ujian masih belum mudah untuk dipahami.

Kedua masih rendahnya tingkat pemahaman siswa didalam memahami materi pelajaran, didukung juga dengan kurangnya sarana dan prasarana dalam pembelajaran dan masih belum mampunya guru-guru dalam mengembangkan RPP dan Silabus berdasarkan karakteristik siswa,

Ketiga masih kurangnya usaha guru dalam mengolah dan menganalisis kembali hasil penilaian, membuat interpretasi tentang kecenderungan hasil penilaian dan menyimpulkan kembali hasil penilaian secara logis dan jelas, guru 
mengungkapkan alasannya bahwa mereka belum atau tidak mempunyai waktu yang cukup untuk melakukan hal-hal demikian.

Keempat bahwa pada saat pembelajaran berlansung masih banyak diantara para siswa yang tidak memperhatikan materi pembelajaran dengan baik, hal ini dilihat dari rendahnya nilai yang mereka peroleh oleh siswa, teknik pembelajaran yang digunakan masih belum bervariasi dan yang biasa dipakai oleh para guru hanya sistem ceramah,

Kelima berdasarkan informasi yang diperoleh dari para informan, upaya yang dapat dilakukan untuk meningkatkan kualitas soal buatan guru mata pelajaran geografi adalah harus ada tim pengembang soal, sehingga dari tahun ketahun soal tersebut dapat dihimpun dengan baik.

Guru diberikan kesempatan untuk melakukan pelatihan-pelatihan baik MGMP tingkat Kabupaten maupun tingkat Propinsi, dan kesempatan untuk melakukan pelatihan harus dilakukan secara berkesinambungan sehingga hasil yang diperoleh dapat dimanfaatkan secara optimal, dan setiap guru mata pelajaran harus diwajibkan untuk membuat, mengolah atau menganalisis kembali butirbutir soal yang diujikan, sehingga hasilnya nanti bisa digunakan untuk membuat soalsoal ujian semester berikutnya menjadi semakin berkualitas.

\section{SIMPULAN}

Berdasarkan deskripsi data hasil penelitian dan pembahasan hasil penelitian maka dapat disimpulkan bahwa Penelitian menunjukkan masih banyaknya soal pilihan ganda buatan guru mata pelajaran geografi SMA Negeri di Kabupaten Tanah
Datar yang belum valid yaitu $38 \%$ soal yang valid dan $62 \%$ soal yang invalid.

Faktor penyebab dari tidak validnya soal pilihan ganda buatan guru mata pelajaran geografi adalah soal yang diujikan kepada siswa masih belum sesuai dengan ketentuan-ketentuan yang telah ditetapkan sebagai kriteria dari mutu soal yang baik.

Masih rendahnya pemahaman siswa terhadap materi yang diajarkan oleh guru, belum adanya upaya dari para guru untuk melakukan analisis terhadap hasil penilaian, dan masih rendahnya motivasi siswa didalam pembelajaran serta teknik yang digunakan pada saat proses pembelajaran terjadi masih belum bervariasi.

Upaya yang dapat dilakukan untuk meninngkatkan kualitas soal buatan guru adalah a) guru-guru harus membuat bank soal, b) guru-guru harus diberikan kesempatan untuk mengikuti pelatihanpelatihan, c) semakin menggalakkan MGMP, d) dan setiap guru mata pelajaran diwajibkan untuk membuat, mengolah atau menganalisis kembali butir-butir soal yang diujikan.

Sesuai dengan kesimpulan yang telah dikemukakan di atas, maka peneliti mencoba memberikan saran-saran sebagai berikut : Diharapkan kepada guru atau tim pembuat soal agar sebelum soal-soal yang dibuat diujikan kepada para siswa sebaiknya soal-soal tersebut di uji dulu tingkat validitas, reabilitas, tingkat kesukaran, daya beda dan keberfungsian pengecoh, sehingga nantinya soal-soal tersebut dapat memenuhi kriteria dari mutu soal yang baik, serta penggunaan bahasa dan petunjuk soal harus lebih jelas, yang dapat memudahkan siswa untuk memahami dan menjawab soal ujian. 
Diharapkan kepada para siswa untuk lebih meningkatkan motivasi dalam belajar, melengkapi sarana dan prasarana didalam pembelajaran terutama buku sumber yang digunakan saat pembelajaran berlansung.

Diharapkan kepada guru-guru mata pelajaran geografi untuk lebih meningkatkan kualitas diri didalam pembelajaran, baik itu dalam pengembangan RPP, Silabus, media maupun teknik yang digunakan didalam pembelajaran.

Kepada kepala sekolah serta instansi terkait diharapkan untuk lebih mengontrol guru-guru disaat proses belajar mengajar berlansung, untuk mengkoordinir guruguru serta siswa didalam kelas dan lebih banyak memberikan kesempatan kepada guru-guru untuk melakukan pelatihan guna pengembangan diri guru dan menambah ilmu pengetahuan.

\section{DAFTAR PUSTAKA}

Albone,Abdul.dkk 2009. Panduan Penyusunan Proposal Penelitian dengan Mudah. Padang : Yayasan Jihadul Khair Center

Anwar,Syafri. 2008. Penilaian Berbasis Kompetensi. Padang : UNP Press

Arikunto.Suharsimi, 2010. Evaluasi Program Pendidikan Pedoman Teoritis Praktis Bagi Mahasiswa dan Praktisi Pendidikan. Jakarta : Bumi Aksara 2006.Prosedur Penelitian Suatu Pendekatan dan Praktik. Jakarta :

\section{Rineka Cipta}

Basrowi,dkk. 2012. Evaluasi Belajar Berbasis Kinerja. Bandung : CV Karya Putra Darwati

Brannen, Julia. 1996. Memadu Metode Penelitian Kualitatif dan Kuantitatif. Samarinda : Fakultas Tarbiyah IAIN Antasari

Departemen Agama. 2007. Kumpulan Undang-undang dan Peraturan Pemerintah RI tentang Pendidikan. Jakarta

Moleong,J.Lexy. 2004. Metodologi Penelitian Kualitatif. Bandung : PT.Remaja Rosdakarya. Rosdakarya 2009. Metodologi Penelitian Kualitatif Edisi Revisi. Bandung : PT.Remaja

Salinan Peraturan Mentri Pendidikan Nasional Republik Indonesia Nomor 19 Tahun 2007 tentang Standar Pengelolaan Pendidikan

Salinan Peraturan Mentri Pendidikan Nasional Republik Indonesia Nomor 20 Tahun 2007 tentang Standar Penilaian Pendidikan

Sudijono Anas. 1996. Pengantar Evaluasi Pendidikan. Jakarta : PT Raja Grafindo Persada 